\title{
Mukhtasar fi Ilm al-Hisab; Islamic Contribution to Malay Mathematics
}

\author{
$1^{\text {st }}$ Humaira Azzahra $^{1}, 2^{\text {nd }}$ Siti Ummi Masruroh ${ }^{2}, 3^{\text {rd }}$ Yusuf Durachman $^{2}$ \\ \{humaira.az13@mhs.uinjkt.ac.id¹,ummi.masruroh@uinjkt.ac.id²,yusuf_durachman@uinjkt.ac.id²\} \\ UIN Syarif Hidayatullah, Islamic Studies Department ${ }^{1}$, \\ UIN Syarif Hidayatullah, Informatics, Jakarta, Indonesia ${ }^{2}$
}

\begin{abstract}
Islam has a pivotal role within the improvement of mathematics, especially inside the brilliant age of classical Muslim science. It is not only in terms of formulas discovery, but also mathematics development through the expansion of Islam across the world. One of the proofs is an Arabic manuscript titled Mukhtasar fi Ilm al-Hisab (Mathematics Summary) by Abdul Qadir bin Ali As-Sakhawi. This manuscript is an important book in Malay mathematics. For that reason, this research aims to indicate the Islamic influence in Malay mathematics through the scientific manuscript. The author used the critical edition method in philology through text editing of the manuscript. The fact seems to suggest that Muslim scholars have a significant impact of mathematical works in the Malay world.
\end{abstract}

Keywords: Mathematics, Malay science, Arabic manuscript, philology.

\section{Introduction}

This Mathematics has been one of the international instruments long before Islam was born. In the history of Islam, mathematics has been developed since the 8th century AD. The ancient Egyptian knew about decimal numbers, solved complicated problems through equations involving squared numbers, calculated circular and spherical areas quite accurately, and in general, could apply the kind of mathematical skills required for such gigantic tasks as planning and building the pyramids at Giza. A thousand years ago before the Christian era, Chinese arithmetic could solve complex problems of measuring geometric areas.

This cognition has also developed in Asia. In India, as far back as the 4th century BC, calculation made by using an algebraic-like method inherited from Babylonia. Decimal system became known in India around the first century AD.

In the first century hijriyah, Muslim scientists used letters of the alphabet in writing their essays to symbolize certain numbers. Mathematics was critical in the whole thing from the calculation of taxes to the division of personal estates in accordance with legal guidelines set forth in The Quran. Mathematical principles and definitions, Greek in origin, have been clarified by Muslim in such a way as to growth public expertise of numerical relationships and promote efficiency in all sort of computation. Muslim mathematicians converted the character of numbers, streamlined some mathematical disciplines and honestly evolved a new department of the mathematics. Meanwhile at the same historical period, Europe's mathematicians were spending their time in working still with Roman numerals. 
The development of mathematics in this era was proven by the discovery of about 10,000 scientific manuscripts in Arabic, Persian and Turkish. Most of these manuscripts came from the most creative period of Islamic science, which spans 8th to 15 th century. Even into the 17 th century, Islamic scholars never stopped obtaining new discoveries in number theory. Some mathematicians, including Hajjaj ibn Yusuf ibn Matar, Muhammad ibn Musa al-Khwarizmi, Abd al-Qadir al-Sakhawi, Abbas ibn Sa'id al-Jawhari, Ya'qub ibn Ishaq al-Kindi, Abu al-Wafaa al-Buzjani, Ahmad ibn Ibrahim al-Euclidis, etc., were the founders and developers of mathematics.

The progress of science in the era of Islamic civilization has spread to the other countries, and Indonesia is one of them. The Middle East country had close relationship with Indonesia since the Islamic civilization era. Initially, the existence of relationship was related to trading, which began in the 8th century AD. This kind of relationship was mostly initiated by Middle Eastern Muslims, especially Arabs and Persians.

In the next phase until the end of the 15 th century, relations between the two regions began to take on broader aspects. Arab and Persian Muslims, both merchants and Sufi travellers, began to intensify the spread of Islam in various regions of Indonesia. At this stage religious and cultural relations are closely combined.

By the 17th century, religious and political relations were also established with Haramayn (Makkah and Madinah). During this period, many Indonesian Muslims went to the two cities to perform the pilgrimage and improve their knowledge at the same time. This encourages the creation of scientific ties between the Middle East and Indonesia through Middle Eastern scholars and Javanese students.

On further investigation, the manuscripts found in Indonesia were mostly religious texts. The abundance of religious texts is indeed not too surprising, especially when considering that the culture of the Indonesian people this day as a whole is the result of the acculturation process of Indonesian society with the Islamic civilization. On the other hand, Muslims do write fewer works in the fields of philosophy, natural sciences and mathematics than in religion and literature, but they still produce a large number of treatises that are still in manuscript form.

Mukhtasar fi Ilm al-Hisab manuscript, which was written by Arabs named Abdul Qadir bin Ali As-Sakhawi As-Syafi' i, is a scientific text, not a religious text. This is what drove the author to reconstruct the scientific texts, in this case the Mukhtasar fi Ilm al-Hisab manuscript, to open the people's horizons about how the ancient scientific text works.

A study about this manuscript was carried out by Ahmad Al-Fathani, the Islamic scholar from Thailand. His book titled Matn as-Sakhawiyah fi 'Ilm al-Hisab contains the analysis of Mukhtasar fi Ilm al-Hisab manuscript which was written in 1304 H / 1886 AD. However, this book is still in the form of a manuscript and not accessible.

\section{Research Methodology}

A qualitative method is conducted in the study. The approach used in conducting the analysis of Mukhtasar fi Ilm al-Hisab manuscript is the critical edition in order to decrease the grammatical errors found in the text. This method used by avoiding errors in the readers' understanding through correcting all kind of deviations that may occur during the copying process. The purpose of this method is to produce text with the best reading quality. 


\section{The Study of Manuscript 3.1 Manuscript Copies}

There are 7 copies of Mukhtasar fi Ilm al-Hisab manuscript which had been stored in different countries, including Japan, England, and Saudi Arabia. The seven copies of the manuscript are as follows.

\begin{tabular}{|l|l|c|}
\hline No & Library & Number of page \\
\hline 1 & $\begin{array}{c}\text { The National Library of Indonesia } \\
\bullet \quad \text { A 455a }\end{array}$ & $\begin{array}{c}8 \text { pages } \\
28 \text { pages }\end{array}$ \\
& $\bullet \quad$ A 455b & 13 pages \\
\hline 2 & $\begin{array}{l}\text { Library of Ali Hasjmy, } \\
\text { Banda Aceh, Indonesia }\end{array}$ & 15 pages \\
\hline 3 & Library of King Saud University, Saudi Arabia & 13 pages \\
\hline 4 & RICAS University of Tokyo, Japan & 5 pages \\
\hline 5 & British Library, United Kingdom & 19 pages \\
\hline 6 & National Library and Archives of Egypt & \\
\hline
\end{tabular}

The manuscript Mukhtasar fi Ilm al-Hisab by Abdul Qadir bin Ali al-Sakhawi has 2 copies in the National Library of Indonesia. Both have calling codes A 455a and A 455b. Besides, the script is also stored in the form of microfilm with roll code 719.04.

Further search, the same copy is also found in the Library of Ali Hasjmy, Banda Aceh, with the code 139B / LL / 20 / YPAH / 2005. In this library, the manuscript was written in 54 pages and bound together with other manuscripts that have different topics. On the cover of the book is given a title Wasilah al-tullab li ma; rifa a'mal al-layli wa al-nahar bi tariq al hisab. The manuscript was copied with naskhi script. There is no the copyist's name and the copy's date, only the name of the owner of the manuscript, Muhammad Yusuf bin Teungku Umar. The manuscript was being donated to the Ali Hasjmy Foundation.

Mukhtasar fi Ilm al-Hisab can also be downloaded on the website http://makhtota.ksu.edu.sa belonging to the King Saud University Library with the code 5954 and number category ms/511. According to data provided by this site, Mukhtasar fi Ilm al-Hisab was composed in $1000 \mathrm{H}$. Then the manuscript was copied in $1305 \mathrm{H}$. The name of the copyist is not stated and the manuscript pages that can be downloaded is also incomplete.

The Research and Information Center for Asian Studies (RICAS) is a research institute under the auspices of the University of Tokyo, Japan, which also keeps copies of Mukhtasar fi Ilm al-Hisab. On the website http://ricasdb.ioc.u-tokyo.ac.jp, the manuscript is listed in a code Ms. 123 [2255] and can be downloaded freely. This text belongs to Ibrahim Ibn Isma'il Ibn Siddiq Ibn Hasan Ibn Arabi al-Ya'qubi al-Maghribi al-Husayni and being copied on 23 Jumadil Ula 1260. Another name for this manuscript is ar-Risalah as-Sakhawiyah. It is consisted of 8 pages. Each page consists of 23 lines and the font size is quite small and as well as the writing is unclear.

A copy of the manuscript was also found in the British Library, UK, on his website http://www.bl.uk/manuscripts with the dial number Or 16773. This manuscript is mixed with other manuscripts with different topic. This collection of manuscripts is entitled "Miscellany (majmu ') on religious matters". The manuscript comes from the 19th century and consists of 17 pages. The type of paper used is European paper. There is a water mark in the form of 3 crescent moon in the manuscript. 
A copy of the manuscript manuscripts can also be downloaded at http://www.wdl.org/en, the U.S Library of Congress's World Digital Library website. The manuscript was copied by Ahmad Al Khalki with the date of manufacture between 1400-1699 AD. The manuscript which was entitled Matan as-Sakhawiyah consists of 20 pages with a paper size of $15.5 \times 21.5 \mathrm{~cm}$. It is a collection belonging to the National Library and Archives of Egypt.

However, most of the manuscript copies are incomplete. Some of their page are missing, incomplete paragraphs (truncated), lack of information about the copy writer, and difficult to be read clearly because of its small font size. Therefore, the author used one copy of Mukhtasar fi Ilm al-Hisab manuscript only as the subject of this study, the manuscript from The National Library of Indonesia with code A $455 \mathrm{~b}$. This is the best one in writing and reading than others.

\begin{tabular}{|c|c|c|c|c|c|}
\hline No & Name of Library & Name of copyist & $\begin{array}{c}\text { Date of } \\
\text { copy }\end{array}$ & Page & Writing \\
\hline 1 & $\begin{array}{l}\text { The National Library of } \\
\text { Indonesia } \\
\text { - A 455a } \\
\text { - A 455b }\end{array}$ & $\begin{array}{l}\text { H. Muhammad } \\
\text { Al-Hasan }\end{array}$ & $1258 \mathrm{H}$ & $\begin{array}{l}\text { Not complete } \\
\text { (Chapter 6-11 } \\
\text { does not } \\
\text { exist) } \\
\text { Complete }\end{array}$ & $\begin{array}{l}\text { Very clear } \\
\text { Very clear }\end{array}$ \\
\hline 2 & $\begin{array}{l}\text { Library of Ali Hasjmy, } \\
\text { Banda Aceh, Indonesia }\end{array}$ & - & - & $\begin{array}{l}\text { Not complete } \\
\text { (Chapter } 8 \\
\text { was cut) }\end{array}$ & Very clear \\
\hline 3 & $\begin{array}{l}\text { Library of King Saud } \\
\text { University, Saudi Arabia }\end{array}$ & - & $1305 \mathrm{H}$ & $\begin{array}{l}\text { Not complete } \\
\text { (Page } 12 \text { does } \\
\text { not exist) }\end{array}$ & Less clear \\
\hline 4 & $\begin{array}{l}\text { RICAS University of } \\
\text { Tokyo, Japan }\end{array}$ & - & $1260 \mathrm{H}$ & Complete & Not clear \\
\hline 5 & $\begin{array}{l}\text { British Library, United } \\
\text { Kingdom }\end{array}$ & - & - & Complete & Very clear \\
\hline 6 & $\begin{array}{l}\text { National Library and } \\
\text { Archives of Egypt }\end{array}$ & Ahmad Khanki & - & Complete & Less clear \\
\hline
\end{tabular}

As additional information, the existence of Mukhtasar fi Ilm al-Hisab is also recorded in several online platform. Here are some of the intended online sources:

\begin{tabular}{|l|l|c|c|}
\hline No & \multicolumn{1}{|c|}{ Name of Library } & Website & Code \\
\hline 1 & Online Library of al-Mostafa & www.al-mostafa.com & 071005 \\
\hline 2 & Netherland Preservation & www.idc.nl/ead & 981 \\
\hline 3 & Bahitsul Ilmi & www.k-tb.com & 17280 \\
\hline 4 & Alukah Library & www.alukah.net & - \\
\hline 5 & Islamic and Arabic manuscripts and books & $\begin{array}{c}\text { www.sites.google.com/sit } \\
\text { e/mokhtoutkotob }\end{array}$ & - \\
\hline
\end{tabular}

\subsection{Manuscript Description}

The author found Mukhtasar fi Ilm al-Hisab manuscript at the National Library of Indonesia, Jakarta, with code A 455b. The manuscript numbered A 455 b was copied by Haji Muhammad Al-Hasan Al-Jawi in 1258 AD. 
In accordance with what Van Ronkel described in his book, Supplement to The Catalogue of the Arabic Manuscripts, this manuscript consists of 14 sheets or 28 pages. Each of the pages has 15 lines, but the last page, 19 lines. There are 2 blank pages in the manuscript, f.13v and f. $15 \mathrm{r}$. In addition, there are 2 pages whose contents are not related to mathematics, $\mathrm{f} .14 \mathrm{r}$ and f. $14 \mathrm{v}$. Both of these pages were slipped from other manuscripts during the binding process.

The paper size is $16.5 \times 22.5 \mathrm{~cm}$. The thickness is $0.7 \mathrm{~cm}$. The cover of the volume is green. There are holes in several places caused by termites. In certain sentences there is a rubrication (red ink), especially at the beginning of the chapter and numbers writing. The type of paper used by this manuscript is European paper.

At the beginning of the manuscript, the author's name is written as Abdul Qadir bin Ali AlSakhawi al-Shafi'i. In addition, there is colophon which gives information about the the copyist's name and the copy's date. The manuscript is written by Haji Muhammad Al Hasan Al-Jawi in Ramadhan 1258 at Mecca, Saudi Arabia.

\subsection{Content of Manuscript}

Mukhtasar fi Ilm al-Hisab manuscript consists of 3 chapters; opening, 11 content sections, and closing. In the opening, 2 forms of Hindi numbering are introduced to express numbers in the manuscript. The 2 forms are:

1.

2.

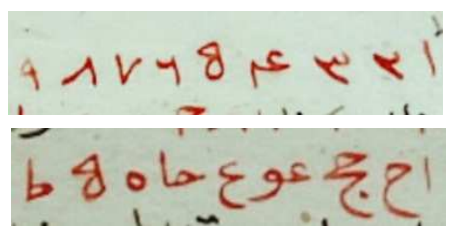

Between the two forms, the first is the most popular one used at that time. The 11 sections explain the basic computation system as follows:

\begin{tabular}{|l|l|}
\hline \multicolumn{1}{|c|}{ Section } & \multicolumn{1}{c|}{ Content } \\
\hline Section 1 & Addition \\
\hline Section 2 & Subtraction \\
\hline Section 3 & Multiplication \\
\hline Section 4 & Division \\
\hline Section 5 & Odd and even numbers \\
\hline Section 6 & Comparison \\
\hline Section 7 & Fraction \\
\hline Section 8 & Fractional addition \\
\hline Section 9 & Fractional subtraction \\
\hline Section 10 & Fractional multiplication \\
\hline Section 11 & Fractional division \\
\hline
\end{tabular}

For the closing, the differential geometry ratio is explained through mathematical question and its calculation.

\subsection{Writing Distinction}

There are several differences in letter writing found in the manuscript. They are as follows. 
- Hamzah (s) in ancient Arabic is written together with ya' (ي). For example in word "ستمائية". While in modern Arabic "ستئة".

- Hamzah Qatha' (أ) in ancient Arabic is written without hamzah on it. For example in word "راس". While in modern Arabic "رأس".

\subsection{Computational System}

The computational system used in the manuscript is longer and more complex than what the people use presently. It is showed by the multiplication and the division method written in the manuscript.

\subsection{Nomenclature of Numbers.}

Arabic nomenclature in fraction for classical mathematics is different from modern mathematics. $\frac{5}{9}$ in classical mathematics is khamsah atsa' (خمسة أتساع) while in modern mathematics called khamsah 'ala tis'ah (خمسة على تسعة).

\section{Islamic Context}

A scientific textual content written through Abdul Qadir bin Ali al-Sakhawi, called Matan al-Sakhawiyah (The shortened Version of Sakhawi), become rewritten via Ahmad Al-Fathani closer to the cease of the nineteenth century. This book was a general text in mathematics and algebra amongst new students in Islamic schools.

The philosophy of studying mathematics within the Malay Islamic global is intently linked to the idea of the relationship among Allah, The Supreme Being and man, his servant. A Muslim is usually aware of this dating and of the truth that something he has at his disposal should be directed to the expression of his enslavement to Allah. Hence within the pursuit of expertise he is continually aware of his position and the roles of information in glorifying the Supreme Being and the confines of his activities in this pursuit. Islam places excessive precedence on the significance of gaining knowledge of. It is a faith whose understanding is predicated substantially on the draw close and the intensity of one's expertise of the physical and nonphysical world.

\section{Conclusions}

This study shows that the getting to know of mathematics became necessary in a Muslim's life, as this situation is a tool in enhancing one's information of the world. The Mukhtasar fi Ilm al-Hisab manuscript shows that there is a pivotal roles of Islam in mathematics development of Malay world. Based on the manuscript, Hindi numbering is commonly used in classical mathematics. However, there are some uniqueness mathematics in ancient times, including:

- Words writing

- Computational system

- Number nomenclature

Acknowledgements. This research supported by The Graduate School of Islamic Studies UIN Syarif Hidayatullah. 


\section{References}

[1] Abdullah, W.: Al'allamah Syeikh Ahmad al-Fathani, Ahli Fikir Islam dan Dunia Melayu, Khazanah Fathaniyah, Kuala Lumpur (1992)

[2] Ali, A., Muhdlor, A.: Kamus Kontemporer Arab Indonesia. Multi Karya Grafika, Yogyakarta (1998)

[3] Asnawi, TB., dkk.: Pedoman Penulisan Skripsi Prodi Bahasa dan Sastra Arab Fakultas Adab dan Humaniora. Adabia Press, Jakarta (2014)

[4] Azra, A.: Jaringan Ulama Timur Tengah dan Kepulauan Nusantara Abad XVII \& XVIII. Prenada Media, Jakarta (2013)

[5] Baried, S., dkk.: Pengantar Teori Filologi. Pusat Penelitian dan Publikasi Fakultas Sastra UGM, Jakarta (1983)

[6] Berggren, J.L.: "Sejarah Matematika di Dunia Islam: Sebuah Penelusuran Bibliografis" in A.I. Sabra dkk, Sumbangan Islam kepada Sains dan Peradaban Dunia. Penerbit Nuansa, Bandung (2001)

[7] Behrend, T.E.: Katalog Induk Naskah-naskah Nusantara Perpustakaan Nasional Republik Indonesia. Yayasan Obor Indonesia, Jakarta (1668)

[8] Chambert-loir, H., Fathurahman, O.: Khazanah Naskah: Panduan Koleksi Naskah-Naskah Indonesia Sedunia-World Guide to Indonesian Manuscript Collections. Yayasan Obor Indonesia, Jakarta (1999)

[9] Fathurahman, O.: Filologi Indonesia: Teori dan Metode. Prenadamedia Group, Jakarta (2015)

[10] Fathurahman, O., Holil, M.: Katalog Naskah Ali Hasjmy Aceh. Tokyo University of Foreign Studies, Tokyo (2007)

[11] Ikram, A.: Filologi Nusantara. PT Dunia Pustaka Jaya, Jakarta (1997)

[12] King, DA.: "Some Remarks on Islamic Scientific Manuscripts and Instruments, and Past, Present, and the Future Research" in John Cooper, ed., The Significance of Islamic Manuscripts: Proceedings of the Inaugural Conference of Al-Furqan Islamic Heritage Foundation. PA 30 November-1 December 1991, Al-Furqan Islamic Heritage Foundation, London (1992)

[13] Lubis, N.: Naskah, Teks, dan Metode Penelitian Filologi. Puslitbang Lektur Keagamaan Depag RI, Jakarta (2007)

[14] Munawwir, AW.: Kamus Al-Munawwir Arab-Indonesia Terlengkap. Pustaka Progressif, Surabaya (1984)

[15] Ronkel, V.: Supplement to The Catalogue of The Arabic Manuscripts Preserved in the Museum of The Batavia Society of Arts and Sciences. Albrecht, London (1913)

[16] Ricklefs, M.C., dkk.: Indonesian Manuscripts in Great Britain New Edition with Addenda et Corrigenda. EFEO, Jakarta (2014)

[17] Turner, H.: Science in Medieval Islam. University of Texas Press, Texas (1997)

[18] Watt, W.: The Influence of Islam on Medieval Europe. Edinburgh University Press, Edinburgh (1972)

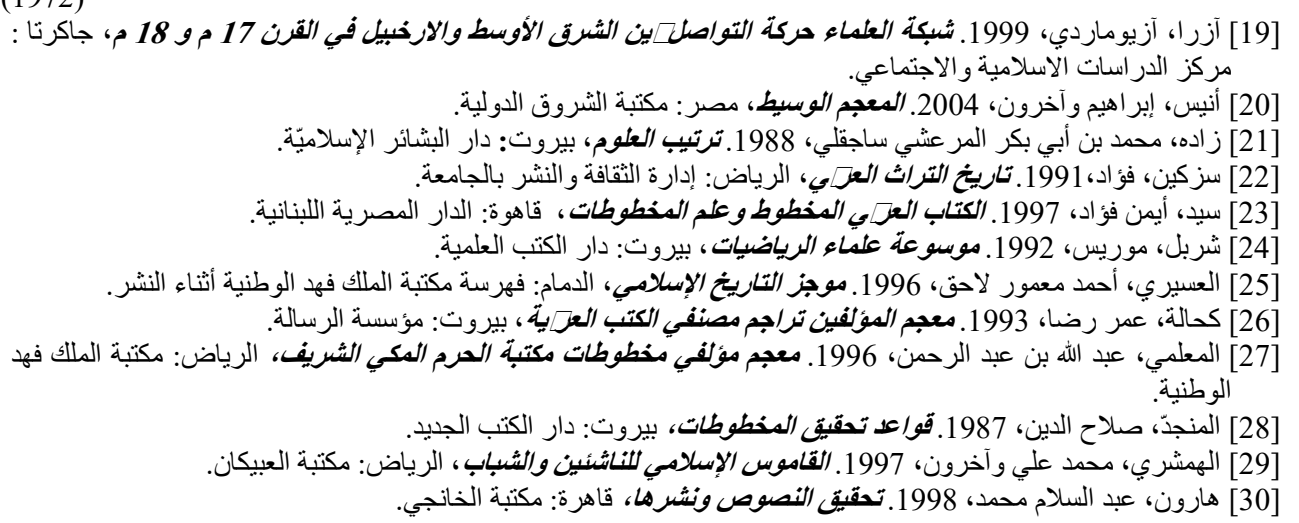

